\title{
Proximate Nutrient Composition of 10 Tropical Forage Grasses ${ }^{1}$
}

\author{
J. Coward-Lord, J. A. Arroyo-Aguilu, and O. Garcia-Molinari $i^{2,8}$
}

\section{INTRODUCTION}

Ten tropical forage grasses (Pangola, Digitaria decumbens; Congo, Brachiaria ruziziensis; Signal, Brachiaria brizantha; Buffel, Cenchrus ciliaris; Guinea, Panicum maximum; Jaragua, Hyparrhenia rufa; Giant Pangola, Digitaria valida; African Crab, Digitaria swazilandensis; Venezuelan Elephant. Pennisetum setosum and Limpo, Hemarthria altissima) were evaluated in terms of proximate chemical composition $(3,14)$ to study the variations in nutritive quality from 30 to 180 days of growth.

Feed analyses have been conducted for the past 100 years by the Weende method, whereby the carbohydrate fraction is partitioned into crude fiber (CF) and nitrogen-free extract (NFE) (14). The difficulties with this system were recognized early by Henneberg and Stohmann (12). In 1938 Crampton and Maynard (6) suggested the accurate separation of the fibrous components and the differentiation of these from the non-fibrous components. However, to establish and evaluate the new methodology in tropical forage grasses more fully, it is necessary to determine their proximate nutrient composition.

\section{PROCEDURE}

The forage grasses, lightly fertilized with $\mathrm{NH}_{4} \mathrm{NO}_{3}$ at the rate of 350 $\mathrm{kg} / \mathrm{ha}$, were harvested from established $10 \mathrm{~m}^{2}$ plots, at the grass collection of the College of Agricultural Sciences, University of Puerto Rico, at Mayagüez. They were harvested by hand (machete) every 30 days for 180 days, beginning August 20,1970, at an approximate height of $10 \mathrm{~cm}$ above soil level. Samples were weighed at the field, dried in an oven at a temperature of $60^{\circ} \mathrm{C}$ and ground in a Wiley mill to pass a $1-\mathrm{mm}$ screen. Total dry matter (TDM) content was calculated.

The samples were subjécted to chemical analyses, namely the Weende

1 Manuscript submitted to Editorial Board February 28, 1973.

2 Data are taken in part from a thesis submitted by the senior author to the Graduate Faculty, College of Agricultural Sciences, University of Puerto Rico, Mayagüez,Puerto Rico, in partial fulfillment of the requirements for the degree of Master of: Science.

${ }^{3}$ Assistant Professor of Pastures, Animal Husbandry Department, Faculty of Agronomy, University of Costa Rica, San José, Costa Rica; Associate Nutritionist, Agricultural Experiment Station, University of Puerto Rico, Rio Piedras, P. R.; and Professor of Agronomy, Faculty of Agriculture, University of Puerto Rico, Mayagüez, Puerto Rico, respectively. 
or proximate analyses (3). These included: crude protein $(\mathrm{N} \times 6.25)(\mathrm{CP})$, CF, ether-extract (EE) and ash (A). NFE was calculated as the difference between 100 and the sum of CP, CF, EE, and $A$.

Statistical analyses were conducted as indicated by Snedecor and Coch$\operatorname{ran}(16)$.

\section{RESULTS AND DISCUSSION}

Data are presented on proximate composition of the 10 forage grasses at the 6 cutting intervals.

TABLE 1.-Crude protein content (percent) of 10 tropical forage grasses at 6 harvest intervals

\begin{tabular}{|c|c|c|c|c|c|c|c|}
\hline \multirow{2}{*}{ Species } & \multicolumn{6}{|c|}{ Harvest Interval (days) } & \multirow{2}{*}{ Meanl } \\
\hline & 30 & 60 & 90 & 120 & 150 & 180 & \\
\hline African Crab. & 18.3 & 9.2 & 8.2 & 7.3 & 6.5 & 5.1 & $9.1^{\mathrm{a}}$ \\
\hline Venezuelan Elephant & 23.7 & 8.6 & 5.0 & 4.0 & 2.8 & 2.1 & $7.7^{\mathrm{ab}}$ \\
\hline Giant Pangola & 17.2 & 8.6 & 5.5 & 5.1 & 4.4 & 4.0 & $7.5^{\mathrm{ab}}$ \\
\hline Pangola & 11.4 & 7.8 & 8.3 & 5.5 & 5.9 & 4.3 & $7.2^{\text {abo }}$ \\
\hline Signal & 16.1 & 9.2 & 4.9 & 2.9 & 4.4 & 3.4 & $6.8^{\mathrm{bo}}$ \\
\hline Buffel & 15.7 & 7.0 & 4.3 & 4.7 & 4.4 & 3.5 & $6.6^{\mathrm{bc}}$ \\
\hline Jaragua & 17.6 & 7.4 & 5.2 & 3.4 & 3.2 & 3.0 & $6.6^{\text {bo }}$ \\
\hline Limpo : & 12.3 & 7.8 & 5.7 & 4.0 & 4.3 & 3.4 & $6.3^{\mathrm{bo}}$ \\
\hline Congo & 15.1 & 5.9 & 3.8 & 3.8 & 2.8 & 2.2 & $5.6^{\text {bo }}$ \\
\hline Guinea & 10.9 & 6.7 & 4.3 &, 4.3 & 2.6 & 1.9 & $5.1^{\circ}$ \\
\hline Mean & 15.8 & 7.8 & 5.5 & 4.5 & 4.1 & 3.3 & 6.8 \\
\hline
\end{tabular}

${ }^{1}$ Mean values with one or more common letter(s) are not significant at the 5percent level.

\section{CRUDE PROTEIN}

The CP content (table 1), a very important soluble component of forage grasses necessary for growth and maintenance of animal tissues, is found in the neutral detergent soluble fraction (22). Digestible protein, obtained from CP times CP digestibility, is of great value in livestock feeding, indicating the potentialities of forages in the animal (1) and presenting a more exact measure of protein value to the animal (18).

Significant 4 differences in CP were observed among grass species. African Crab grass obtained the highest mean value, significantly different from Signal, Buffel, Jaragua, Limpo, Congo, and Guinea grasses.

Highly significant ${ }^{5}$ differences in CP, ranging from 15.8 to 3.3 percent, were observed, as grasses advanced in maturity up to 180 days. The largest

1 Significant at the 5-percent level.

5 Significant at the 1-percent level. 
reduction ( 8.0 percentage units) was obtained between 30 and 60 days of age, in contrast to reductions of 2.3, 1.0, 0.4 and 0.8 units at $90,120,150$ and 180 days, respectively. The decrease in CP content occurred early in the growing season. Similar results were obtained by Gomide et al. (10), Tergas et al. (19) and Grieve and Osbourn (11).

\section{TOTAL DRY MATTER}

The TDM content (tables 2 and 3 ) revealed highly significant differences with respect to species and age. Mean values for species ranged from 42.2 to 28.6 percent for Buffel and Venezuelan Elephant grasses, respectively. Venezuelan Elephant grass had the lowest TDM content (12.2 percent) of all grass species at 30 days, increasing to 51.0 percent at 180 days. On the other hand, Buffel grass showed a higher TDM content (21.1 per-

TABLE 2.-Mean total dry matter, crude fiber, ether-extract, nitrogen-free extract and ash contents (percent) of 10 tropical grasses at 6 harvest intervals ${ }^{2}$

\begin{tabular}{|c|c|c|c|c|c|}
\hline Species & $\begin{array}{l}\text { Total } \\
\text { dry matter }\end{array}$ & Crude fiber & $\begin{array}{c}\text { Nitrogen } \\
\text { free extract }\end{array}$ & $\underset{\text { extract }}{\text { Ether }}$ & Ash \\
\hline African Crab & $34.9^{b}$ & $30.0^{d}$ & $50.3^{\mathrm{ab}}$ & $1.9^{\mathrm{a}}$ & $8.7^{\circ}$ \\
\hline Venezuelan Elephant & $28.6^{\circ}$ & $37.4^{\text {abo }}$ & $45.1^{d}$ & $1.8 \mathrm{ab}$ & $8.0^{\mathrm{ab}}$ \\
\hline Giant Pangola & $37.0^{\mathrm{b}}$ & $33.0^{\text {do }}$ & $49.5^{\mathrm{ab}}$ & $2.2^{\mathrm{a}}$ & $7.8^{\mathrm{ab}}$ \\
\hline Pangola & $29.5^{\text {cdo }}$ & 34.000 & $49.0^{\mathrm{b}}$ & $1.9^{\mathrm{a}}$ & $7.9^{\mathrm{ab}}$ \\
\hline Signal & $32.9^{\text {bed }}$ & $33.7^{\circ 0}$ & $50.6^{\mathrm{ab}}$ & $1.8^{\mathrm{ab}}$ & $7.1^{\mathrm{b}}$ \\
\hline Buffel & $42.2^{a}$ & $38.0^{\circ \mathrm{b}}$ & $45.5^{\text {ed }}$ & $1.3^{\circ}$ & $8.6^{\mathrm{a}}$ \\
\hline Jaragua & $33.3^{\text {bo }}$ & $34.7^{b 00}$ & $48.2^{\text {bo }}$ & $1.8^{\mathrm{ab}}$ & $8.7^{a}$ \\
\hline Limpo & $34.7^{b}$ & $35.1^{\text {bco }}$ & $52.3^{a}$ & $1.4^{\mathrm{bo}}$ & $4.9^{\circ}$ \\
\hline Congo & $35.5^{b}$ & $36.1^{\text {boe }}$ & $49 \cdot 5^{\mathrm{ab}}$ & $1.8^{\mathrm{ab}}$ & $7.0^{\mathrm{b}}$ \\
\hline Guinea & $34.1^{\mathrm{b}}$ & $40.7^{a}$ & $45.3^{\text {ed }}$ & $1.4^{\mathrm{bo}}$ & $7.5^{\mathrm{ab}}$ \\
\hline Mean & 34.3 & 35.3 & 48.5 & 1.7 & 7.7 \\
\hline
\end{tabular}

1 Mean values with one or more common letter(B) are not significant at the 5percent level.

Table 3.-Mean total dry matter, crude fiber, nitrogen-free extract and ash contents (percent) of 6 harvest intervals

\begin{tabular}{cccccc}
\hline Harvest interval & $\begin{array}{c}\text { Total dry } \\
\text { matter }\end{array}$ & Crude fber & $\begin{array}{c}\text { Nitrogen } \\
\text { free extract }\end{array}$ & Etber extract & Ash \\
\hline Days & & & & & \\
30 & 20.5 & 31.3 & 39.7 & 2.4 & 10.8 \\
60 & 21.7 & 36.0 & 45.9 & 1.9 & 8.4 \\
90 & 30.2 & 36.4 & 49.7 & 1.8 & 6.6 \\
120 & 35.7 & 36.7 & 50.5 & 1.4 & 6.9 \\
150 & 43.4 & 35.4 & 52.1 & 1.5 & 6.9 \\
180 & 54.0 & 35.8 & 53.4 & 1.4 & 6.1 \\
Mean & 34.3 & 35.3 & 48.5 & 1.7 & 7.7 \\
\hline
\end{tabular}


cent) at 30 days, increasing to 69.9 percent at 180 days, the highest TDM content of all species. Similar results were obtained for Pangola grass by Arroyo-Aguilú et al. (2), Chicco (4), Gomide et al. (10), Grieve and Osbourn (11) and Vicente-Chandler et al. (24); for Congo grass by ArroyoAguilú et al. (2); and for Guinea grass by Rivera-Brenes et al. (15) and Johnson et al. (13).

As grasses advanced in maturity from 30 to 180 days, TDM content increased. As a result, moisture content was reduced, as grasses became less tender and more fibrous (5). The largest TDM increase was observed between 150 and 180 days (10.6 units). However, from 60 days of age forward, the TDM increase became larger, in line with the reduction in CP.

\section{CRUDE FIBER}

The definition of CF (23) as a chemically uniform substance as cellulose (C) cannot be reconciled with the view that $\mathrm{CF}$ represents the least digestible part of the forage and therefore includes lignin (L). Originally CF (tables 2 and 3) (21) was regarded as a non-nutritive residue, but the imperfect CF methodology has allowed most of the $L$ and hemicellulose $(H)$ to be extracted into' the NFE, which is supposed to represent available carbobohydrates. In some cases the CF (12) was more digestible than the NFE, whose indigestible portion was the non-carbohydrate L. Goering and Van Soest (9) separated the total fiber fraction, by means of detergent techniques into more meaningful and precise components: neutral-detergent fiber and acid-detergent fiber or lignocellulose. These, in turn, were separated into $\mathrm{L}$, cellulose, $\mathrm{H}$ and silica.

Highly significant differences were observed among species and age of grasses. The highest increase ( 4.7 units) occurred between 30 and 60 days with a low decrease (1.3 units) thereafter up to 120 and 150 days of age as grasses advanced in maturity. The sharp rise in CF at early ages (30 to 60 days of growth) was evident in all grasses except Pangola, in which case there was a CF reduction of 2.3 units from 30 to 60 days and of 7.4 units from 30 to 180 days. Similar results in Pangola grass were observed by Arroyo-Aguilú et al. (2) between 40 to 46 and 54 to 60 days of growth and by Tessema (20) between 28 and 63 days of growth, respectively. Gomide et al. (10) obtained a slight increase in CF content of Pangola grass as it matured from 28 to 259 days, in contrast to a sharp increase in Merker grass.

NITROGEN-FREE EXTRACT, ETHER EXTRACT AND ASH

The NFE fraction (tables 2 and 3) is supposed to represent the soluble carbohydrate fraction; however, due to the limitations of the CF deter- 
mination, this is not always the case. Sullivan (17) showed that the NFE contains some of the $\mathrm{C}$, nearly all of the $\mathrm{H}$, which has the same digestibility as the $\mathrm{C}$, and a large share of the $\mathrm{L}$ which has a very low digestibility. Fonnesbeck (7) pointed out the failure of the CF and NFE fractions to accurately represent carbohydrate materials.

Highly significant differences in NFE content were observed among species and age of grasses. Limpo and Venezuelan Elephant grasses exhibited the highest $(52.3 \%)$ and the lowest (45.1\%) mean NFE values, respectively. The largest NFE increase (6.2 units) occurred between 30 and 60-day cutting intervals. Similar results in NFE content were obtained by Arroyo-Aguilú et al. (2).

The EE fraction (tables 2 and 3) represents the lipid constituents of the forage. Fraps and Rather (8) indicated that the EE fraction is a poor index of the fatty acid content. Van Soest (22) suggested that the use of the empirical factor 2.25 to multiply the EE fraction in the proximate analyses is inaccurate.

The EE, content revealed highly significant differences with respect to species and plant age. Decreasing rates in EE content were observed as the grasses matured from 30 to 120 days, with the largest reductions $(0.5$ units) occurring between 30 and 60 days. Although no statistical significance was obtained in Pangola, Congo and Star grasses by Arroyo-Aguilú et al. (2), similar trends were evident.

The inorganic or mineral constitutents of forages are represented in the A fraction (tables 2 and 3 ). With respect to species and plant age, highly significant differences in A content were obtained, the largest reductions occurring between 30 and 60 days. Similar results were obtained by Arroyo-Aguilú et al. (2) in Pangola, Congo and Star grasses. The A fraction may prove more meaningful in terms of individual mineral contents.

\section{SUMMARY}

Ten tropical forage grasses (Pangola, Digitaria decumbens; Congo, Brachiaria ruziziensis; Signal, Brachiaria brizantha; Buffel, Cenchrus ciliaris; Guinea, Panicum maximum; Jaragua, Hyparrhenia rufa Giant Pangola, Digitaria valida; African Crab, Digitaria swazilandensis; Venezuelan Elephant, Pennisetum setosum; and Limpo, Hemarthria altissima), lightly fertilized with $\mathrm{NH}_{4} \mathrm{NO}_{3}$ at the rate of $350 \mathrm{~kg} / \mathrm{ha}$, were harvested by hand (machete) every 30 days during 180 days, beginning on August 20, 1970, at the College of Agricultural Sciences grass collection, University of Puerto Rico at Mayagüez. Total dry matter (TDM) content was calculated.

Forages studied were evaluated chemically for crude protein $(\mathrm{N} \times 6.25)$ (CP), crude fiber (CF), ether extract (EE) and ash (A). NFE was calcu- 
lated as the difference between 100 and the sum of CP, CF, EE and A. Statistical analyses of variance were conducted.

All fractions differed in a highly significant way with respect to species and plant age. Highly significant differences in CP, $\mathrm{EE}$ and $\mathrm{A}$ at decreasing rates and in TDM, CF and NFE at increasing rates were obtained, as the grasses advanced in maturity. The largest changes in forage quality occurred between 30 and 60 days of age.

\section{RESUMEN}

Se evaluaron muestras de las siguientes 10 yerbas forrajeras tropicales: Pangola, Digitaria decumbens; Congo, Brachiaria ruziziensis; Buffel, Cenchrus ciliaris; Guinea, Panicum maximum; Jaragua, Hyparrhenia rufa; Pangola Gigante, Digitaria valida; "African Crab", Digilaria swazilandensis; Elefante Venezolana, Pennisetum setosum y Limpo, Hemarthria altissima, de 30 a 180 dias de edad, tomadas a intervalos de corte de 30 días comenzando el 20 de agosto de 1970.

Las yerbas se encontraban ya establecidas en parcelas con un área de $10 \mathrm{m.} .^{2} \mathrm{en}$ la colección de gramineas del Colegio de Ciencias Agrícolas de la Universidad de Puerto Rico, localizada en Mayagüez. Se abonaron ligeramente con $\mathrm{NH}_{4} \mathrm{NO}_{3}$ a razón de 350 kg./ha. Se determinó el contenido de materia seca total (TDM).

Se efectuaron determinaciones químico-analíticas de la proteina cruda $(N \times 6.25)$ (CP), la fibra cruda (CF), el extracto etéreo (EE) y la ceniza (A). El extracto libre de nitrógeno (NFE) se determinó como la diferencia entre 100 y la suma de la CP, la CF, el EE y la A. Los resultados se analizaron estadisticamente por el método de varianza.

Se encontraron diferencias altamente significativas en todos los componentes con respecto a las especies forrajeras y a las edades de corte. Según fueron madurando las yerbas disminuyeron la CP, el EE y la A, mientras que la TDM, la CF y el NFE aumentaron con diferencias altamente significativas. El mayor cambio en valor nutritivo tuvo lugar entre los 30 y los 60 días de edad.

\section{LITERATURE CITED}

1. Arroyo-Aguila, J. A., and Rivera-Brenes, L., Relationship between the percentages of crude protein and apparently digestible protein in some forages of Puerto Rico, J. Agr. Univ. P. R. 49 (1): 145-8, 1965.

2. - - - De Arce, M., and Acosta-Matienzo, A., Valor nutritivo y consumo voluntario de las gramineas Pangola (Digitaria decumbens), Congo (Brachiaria ruziziensis y Estrella (Cynodon nlemfuensis), A.L.P.A. Mem. 8: 91-106, 1973.

3. Association of Official Analytical Chemists, Official Methods of Analysis, 11th ed., Washington, D. C., 1970.

4. Chicco, C. R., Estudio de la digestibilidad de los pastos en Venezuela, IV, Valor nutritivo del pasto Pangola (Digitaria decumbens) en varios estados de crecimiento, Agron. Trop. 12: 57-64, 1962.

5. Coward-Lord, J., Arroyo-Aguilu, J. A., and Garcia Molinari, O., Fibrous carbohydrate fractions and in vitro true and apparent digestibility of ten typical forage grass, J. Agr. Univ. P. R. 58 (3): 293-304, 1974.

6. Crampton, E. W., and Maynard, L. A., The relation of cellulose and lignin content to the nutritive value of animal feeds, J. Nutr. 15: 383-95, 1938.

7. Fonnesbeck, P. V., Partitioning the nutrients of forage for horses, J. Anim. Sci. 28: 624-33, 1969. 
8. Fraps, G. S., and Rather, J. B., Composition and digestibility of the ether extract of hays and fodders, Texas Agr. Exp. Sta. Bull. 150, 1912.

9. Goering, H. K., and Van Soest, P. J., Forage fiber analyses (apparatus, reagents, procedures, and some applications), USDA. Agr. Handbook 379, 1970.

10. Gomide, J. A., Noller, C. H., Mott, G. O., Conrad, H. H., and Hill, D. L., Effect of plant age and nitrogen fertilization on the chemical composition and in vitro cellulose digestibility of tropical grasses, Agron. J. 61: 116-20, 1969.

11. Grieve, C. M., and Osbourn, D.F., The nutritional value of some tropical grasses, J. Agr. Sci. 65: 411-7, 1965.

12. Henneberg, W., and Stohmann, F., Begrundung einer rationellen Fütterung der Wiederkaver, II, Schwetschtke und Sohn, Braunschweig, Deutschland, 1864 (from J. Anim. Sci. 23: 838-45, 1964).

13. Johnson, W. L., Hardison, W. A., and Castillo, L. S., The nutritive value of Panicum maximum (Guinea grass), I, Yields and chemical composition related to season and herbage growth stage, J. Agr. Sci. 69: 155-60, 1967.

14. Maynard, L. A., and Loosli, J. K., Animal Nutrition, 6th ed., McGraw-Hill Book Co., Inc., New York, N. Y., 1965.

15. Rivera-Brenes, L., Arroyo, J. A., and Acosta-Matienzo, A., Acceptability Trials on Buffel grass (Cenchrus ciliaris) and Guinea grass hybrid (Panicum maximum), as compared with Napier (Merker) Grass (Pennisetum purpureum), J. Agr. Univ. P. R. 52 (2) : 77-84, 1968.

16. Snedecor, G. W., and Cochran, W. G., Statistical Methods, 6th ed., The Iowa State Univ. Press, Ames, Iowa, 1967.

17. Sullivan, J. T., Evaluation of forage crops by chemical analysis, A critique, Agron. J. 54: 511-5, 1962.

18. - Chemical composition of forages with reference to the needs of the grazing animal, USDA. Agr. Res. Ser. 34-107, 1969.

19. Tergas, L. E., Blue, W. G., and Moore, J. E., Nutritive value of fertilized Jaragua grass (Hyparrhenia rufa (Nees) Stapp.) in the wet-dry Pacific region of Costa Rica, Trop. Agr. 48: 1-8, 1971.

20. Tessema, S., Nutritional value of some tropical grass species compared to some temperate grass species, Ph.D. Thesis, Cornell Univ., 1972.

21. Thaer, A., Grundsätze der rationellen Landwirtschaft, I, Sect. 275, Die Realschulbuchhandlung, Berlin, Deutschland, 1809 (from J. Anim. Sci. 26: 119-28, 1967).

22. Van Soest, P. J., Symposium on nutrition and forage and pastures: New chemical procedures for evaluating forages, J. Anim. Sci. 23: 838-45, 1964.

23. - - Development of a comprehensive system of feed analyses and its application to forages, J. Anim. Sci. 26: 119-28, 1967.

24. Vicente-Chandler, J., Figarella, J., and Silva, S., Effects of nitrogen fertilization and frequency of cutting on the yield and composition of Pangola grass in Puerto Rico, J. Agr. Univ. P. R. 45 (1) : 37-45, 1961. 